\title{
BIOREMEDIATION OF CLAY SOILS IMPACTED BY PETROLEUM
}

\author{
Pala, Danielle Marins ${ }^{1 *}$; \\ Freire, Denize Dias de Carvalho²; \\ Sant'Anna Jr., Geraldo Lippel ${ }^{3}$ \\ ${ }^{1 *}$ UFRJ, COPPE/ Programa de \\ Engenharia Química, \\ dmarins@ peq.coppe.ufrj.br, \\ Fax: $+55.21 .562-8300$, Brazil. \\ ${ }^{2}$ UFRJ, Escola de Química / Departamento de \\ Engenharia Bioquímica, \\ denize@eq.ufrj.br, \\ Fax: +55.21.562-7567, Brazil. \\ ${ }^{3}$ UFRJ, COPPE/Programa de \\ Engenharia Química, \\ lippel@peq.coppe.ufrj.br \\ Fax: +55.21.562-8300, Brazil.
}

\begin{abstract}
The application of bioremediation processes in recuperating contaminated sites is gaining ground, due to its efficiency in removing a number of different classes of contaminants and its cost, which tends to be lower than that of other technologies. In this work, the influence of some factors that are important for the biodegradation of the petroleum present in clay soil was studied. Experiments were conducted using two types of reactor, a slurry-phase reactor and a fixed bed reactor. The processes employed were shown to be highly effective in decontaminating the soil, achieving removal rates of around $80 \%$.
\end{abstract}

Key words: Bioremediation, clay soils, petroleum

\section{INTRODUCTION}

The petroleum industry is behind a number of environmental impacts resulting from accidental spills of oil and its derivatives. The biodegradability of these products depends on the chemical structure of their components. This being the case, the lighter and more soluble the chemical, the greater its biodegradability ${ }^{1}$.

In the past, physicochemical methods were predominantly employed to recuperate contaminated soils. Today, however, there exist a number of studies demonstrating that bioremediation could be efficient in treating soils and sediments contaminated by petroleum and its derivatives, added to which it is cheaper. These processes are based on the ability of microorganisms to degrade a number of different types of substances present in the environment. Evidently, the degrees of degradation obtained in the literature are different according to the type of soil, the type and concentration of the pollutants, as well as the availability of nutrients and oxygen ${ }^{2-6}$.

There have only been a few studies done on the bioremediation of clay soils, so this study intends to assess the biodegradability of the compounds present in a clayey soil contaminated with crude oil.
To do so, a number of experiments were undertaken in slurry-phase and fixed bed reactors. The data obtained in the latter tests were used to prepare an experimental design to evaluate the influence of variables considered relevant in the bioremediation process.

\section{MATERIALS AND METHODS}

\section{CONTAMINATED SOIL}

The contamination took place in an accident at the end of 1998, in which around 1000 tons of soil were contaminated with crude oil. This material is stored at the accident site, where there is a transfer station for petroleum and its derivatives.

To do the present work, a representative sample of the soil was removed, and was subsequently triturated and homogenized.

\section{PHYSICOCHEMICAL ANALYSES}

Organic Carbon Content: The organic carbon was measured using the Walkley and Black method ${ }^{8}$.

Oil and Grease: The analysis made included the 
substances present in the soil that were soluble in hexane, extracted according to the methodology described in section 5220 C of the Standard Methods ${ }^{7}$.

Nutrients $(N, P)$ : The nitrogen content in the soil was measured using the Kjeldahl steam distillation method. Phosphorous was measured using the total phosphorous method $^{8}$.

$p H$ : The soil's actual acidity (in distilled water) and potential acidity (in a solution of $\mathrm{KCl} 1 \mathrm{~N}$ ) were measured ${ }^{8}$.

Total Water Content: The method described in the Manual de Métodos de Análise de Solo published by EMBRAPA $^{9}$ was used to determine the soil's water content.

Density of Particles: The density measurement was made with the help of $60 \mathrm{~mL}$ pycnometers ${ }^{8}$.

\section{ENUMERATION OF BACTERIA}

To evaluate the microbial population, the samples collected were placed in contact with a $0.85 \% \mathrm{NaCl}$ solution and shaken for 30 minutes, to extract the bacteria present in the soil.

The total heterotrophic bacteria were counted according to the surface spread method. The hydrocarbonoclastic bacteria count was done using the most probable number method, with crude oil from the Cabiúnas plant serving as a source of carbon. ${ }^{10}$

\section{INOCULUM}

The inoculum was developed from microorganisms that occur naturally in the soil and from activated sludge, with the addition of crude oil as a source of carbon, stimulating the growth of the microbial population by adding appropriate nutrients.

To do so, a mechanically aerated, agitated reactor with a working volume of $1.5 \mathrm{~L}$ was used, containing $20 \%$ soil, $5 \%$ activated sludge, $2 \%$ crude oil, $0.05 \%$ yeast extract and $72.95 \%$ Bushnell Haas broth $\left(0.20 \mathrm{~g} / \mathrm{L} \mathrm{MgSO}_{4}, 0.02 \mathrm{~g} / \mathrm{L} \mathrm{CaCl}_{2}, 1.00 \mathrm{~g} / \mathrm{L}\right.$ $\mathrm{KH}_{2} \mathrm{PO}_{4}, 1.00 \mathrm{~g} / \mathrm{L} \mathrm{K}_{2} \mathrm{HPO}_{4}, 1.00 \mathrm{~g} / \mathrm{L} \mathrm{NH}_{4} \mathrm{NO}_{3}$ and $0.05 \mathrm{~g} / \mathrm{L} \mathrm{FeCl}_{3}$ ).

\section{BIODEGRADABILITY TESTS}

During the biodegradability tests, the influence of three variables ( $\mathrm{pH}$, nitrogen content and ratio of soil to water) on the biodegradation of the pollutants present in the soil was assessed. These experiments were conducted in slurry-phase reactors with a working capacity of $125 \mathrm{~mL}$, shaken at $200 \mathrm{rpm}$ for 13 days at ambient temperature, according to the conditions set out in Table 1.

The extremely favorable moisture conditions characteristic of this type of experiment make it possible for results to be obtained quickly on the feasibility of bioremediation as a means of treating the soil in question.

\begin{tabular}{c|c|c|c}
\hline Reactor & $\begin{array}{c}\text { Nitrogen } \\
\text { Content }\end{array}$ & $\mathbf{p H}$ & Mass of Soil \\
\hline $\mathbf{1}$ & $0.07 \%$ & 5.0 & $25 \mathrm{~g}$ \\
\hline $\mathbf{2}$ & $0.07 \%$ & 7.0 & $50 \mathrm{~g}$ \\
\hline $\mathbf{3}$ & $0.07 \%$ & 5.0 & $50 \mathrm{~g}$ \\
\hline $\mathbf{4}$ & $0.07 \%$ & 7.0 & $25 \mathrm{~g}$ \\
\hline $\mathbf{5}$ & $0.5 \%$ & 5.0 & $25 \mathrm{~g}$ \\
\hline $\mathbf{6}$ & $0.5 \%$ & 5.0 & $50 \mathrm{~g}$ \\
\hline $\mathbf{7}$ & $0.5 \%$ & 7.0 & $25 \mathrm{~g}$ \\
\hline $\mathbf{8}$ & $0.5 \%$ & 7.0 & $50 \mathrm{~g}$ \\
\hline
\end{tabular}

Table 1 - Experimental conditions of the tests conducted in slurryphase reactors.

\section{EXPERIMENTS USING A FIXED BED (EXPERIMENTAL DESIGN)}

These experiments were held in bioreactors made up of columns $20 \mathrm{~cm}$ high with a $5 \mathrm{~cm}$ radius, kept at ambient temperature. The influence of three variables (nitrogen content, $\mathrm{pH}$ and aeration rate) on the pollutant removal efficiency was assessed for 30 days. Table 2 shows the experimental conditions for each reactor.

The lowest nitrogen content and $\mathrm{pH}$ levels $(0.07 \%$ and 5 , respectively) were the natural values for these variables in the soil. The highest nitrogen level $(0.5 \%)$ obeyed the C:N:P ratio of 100:10:1 and was obtained by adding $\mathrm{NH}_{4} \mathrm{NO}_{3} \cdot \mathrm{pH} 7$ was chosen as the highest level as it is suitable for microbial growth; it was adjusted by adding a $0.1 \mathrm{~N} \mathrm{NaOH}$ solution.

In all the reactors, the water content was corrected so that it stayed around the $25 \%$ level. The inoculum itself was used to increase the water content in the soil, except for reactors 19 and 20 (control experiments with no inoculum), to which distilled water was added.

\begin{tabular}{c|c|c|c}
\hline Reactor & $\begin{array}{c}\text { Nitrogen } \\
\text { Content }\end{array}$ & $\mathbf{p H}$ & $\begin{array}{c}\text { Aeration } \\
\text { Rate }\end{array}$ \\
\hline $\mathbf{1 / 9}$ & $0.5 \%$ & 7.0 & $6 \mathrm{~L} / \mathrm{h}$ \\
\hline $\mathbf{2 / 1 0}$ & $0.07 \%$ & 7.0 & $6 \mathrm{~L} / \mathrm{h}$ \\
\hline $\mathbf{3 / 1 1}$ & $0.5 \%$ & 5.0 & $6 \mathrm{~L} / \mathrm{h}$ \\
\hline $\mathbf{4 / 1 2}$ & $0.07 \%$ & 5.0 & $6 \mathrm{~L} / \mathrm{h}$ \\
\hline $\mathbf{5 / 1 3}$ & $0.5 \%$ & 7.0 & $3 \mathrm{~L} / \mathrm{h}$ \\
\hline $\mathbf{6 / 1 4}$ & $0.07 \%$ & 7.0 & $3 \mathrm{~L} / \mathrm{h}$ \\
\hline $\mathbf{7 / 1 5}$ & $0.5 \%$ & 5.0 & $3 \mathrm{~L} / \mathrm{h}$ \\
\hline $\mathbf{8} / \mathbf{1 6}$ & $0.07 \%$ & 5.0 & $3 \mathrm{~L} / \mathrm{h}$ \\
\hline $\mathbf{1 7 / 1 8}$
\end{tabular}

17/18 - Control Experiments with inoculum

19/20 - Control Experiments with no inoculum

Table 2 - Experimental conditions for the experiments conducted in fixed bed bioreactors.

With the results obtained in the experiments, $2^{3}$ full factorial experimental design was done with three factors at two levels to assess more precisely what influence the factors under analysis had on the removal efficiency.

The analyses were done in duplicate and the control variable used was the soil's organic carbon content. 


\section{RESULTS AND DISCUSSION}

\section{CHARACTERIZATION OF THE SOIL}

The main physicochemical characteristics of the soil are shown in Table 3.

\begin{tabular}{l|c|c|c|c|c|c|c}
\hline & $\begin{array}{c}\text { Density } \\
\left(\mathbf{g} / \mathrm{cm}^{3}\right)\end{array}$ & Real pH & $\begin{array}{c}\text { Potential } \\
\mathbf{p H}\end{array}$ & $\begin{array}{c}\text { \% } \\
\text { Nitrogen }\end{array}$ & $\begin{array}{c}\text { Phosphorous } \\
(\mathbf{p p m})\end{array}$ & $\begin{array}{c}\text { \% Organic } \\
\text { Carbon }\end{array}$ & $\begin{array}{c}\text { \% Oil \& } \\
\text { Grease }\end{array}$ \\
\hline $\begin{array}{l}\text { Non-contaminated } \\
\text { Soil }\end{array}$ & 2.60 & 5.6 & 5.2 & 0.011 & 0.25 & 0.30 & - \\
\hline Contaminated Soil & 1.97 & 5.4 & 4.5 & 0.073 & 0.28 & 5.05 & 8.0 \\
\hline
\end{tabular}

Table 3 - Results of the characterization of contaminated and noncontaminated soil.

The high levels of organic carbon and oil \& grease present in the sample indicate the contamination of the soil, added to which the diminished density of the contaminated soil as compared to the uncontaminated soil indicates the presence of hydrocarbons.

As regards the nutrients, the soil is very poor in nitrogen but contains enough phosphorous for the activity of the microorganisms.

The soil in question has an acidic $\mathrm{pH}$, as is characteristic of most Brazilian soils.

\section{ENUMERATION OF BACTERIA}

The microbial count showed a low number of microorganisms in the soil. An inoculum was developed to be added to the soil in the tests to be conducted in a fixed bed reactor, so as to try and improve the biodegradatory efficiency of the contaminants.

Table 4 shows the values obtained in the microbial count of the soil and of the inoculum. It can be seen that the latter contains a larger microbial population, both of total heterotrophic bacteria and of hydrocarbonoclastic bacteria.

\begin{tabular}{l|l|l}
\hline & \multicolumn{1}{|c}{ Soil } & \multicolumn{1}{c}{ Inoculum } \\
\hline Total Heterotrophic Bacteria & $6.0 \times 10^{4} \mathrm{CFU} / \mathrm{g}$ (dry soil) & $1.01 \times 10^{8} \mathrm{CFU} / \mathrm{mL}$ \\
\hline Hidrocarbonoclastic Bacteria & $1.75 \times 10^{2} \mathrm{MPN} / \mathrm{g}$ (dry soil) & $3.5 \times 10^{6} \mathrm{MPN} / \mathrm{mL}$ \\
\hline
\end{tabular}

Table 4 - Results of the microbial count of the soil.

\section{BIODEGRADABILITY TESTS}

The contaminant removal efficiency in each of the biodegradability tests can be seen in Table 5 .

\begin{tabular}{c|c}
\hline Reactor & $\begin{array}{c}\text { Removal } \\
\text { Percentages }\end{array}$ \\
\hline $\mathbf{1}$ & 9 \\
\hline $\mathbf{2}$ & 1 \\
\hline $\mathbf{3}$ & 2 \\
\hline $\mathbf{4}$ & 0 \\
\hline $\mathbf{5}$ & 31 \\
\hline $\mathbf{6}$ & 13 \\
\hline $\mathbf{7}$ & 19 \\
\hline $\mathbf{8}$ & 45 \\
\hline
\end{tabular}

Table 5 - Contaminant removal efficiency in the fixed bed tests.
According to the results obtained, it may be said that the pollutants present in the soil can be biodegraded by the naturally occurring microbial flora. Furthermore, it can be seen that runs 5 and 8 show the highest removal percentages, at $31 \%$ and $45 \%$, respectively. This indicates the influence of the $\mathrm{pH}$ and nitrogen content on the biodegradation of the pollutants.

\section{TESTS IN A FIXED BED (EXPERIMENTAL DESIGN)}

Table 6 shows the contaminant removal efficiency for each reactor utilized. The tests conducted under the same conditions (in duplicate) presented similar results, which demonstrates their reproducibility.

If we compare the results obtained from reactors 19 and 20 (control experiments with no inoculum) with the others, it seems that the addition of an inoculum does not improve the efficiency of the process. This fact has already been cited in the literature ${ }^{6}$.

\begin{tabular}{c|c|c}
\hline Reactor & $\begin{array}{c}\text { Removal } \\
\text { Percentages }\end{array}$ & $\begin{array}{c}\text { Standard } \\
\text { Deviation }\end{array}$ \\
\hline $\mathbf{1 / 9}$ & $39 / 42$ & 2 \\
\hline $\mathbf{2} / \mathbf{1 0}$ & $72 / 65$ & 5 \\
\hline $\mathbf{3 / 1 1}$ & $44 / 39$ & 4 \\
\hline $\mathbf{4 / 1 2}$ & $58 / 59$ & 1 \\
\hline $\mathbf{5 / 1 3}$ & $31 / 27$ & 3 \\
\hline $\mathbf{6 / 1 4}$ & $79 / 73$ & 4 \\
\hline $\mathbf{7 / 1 5}$ & $28 / 33$ & 4 \\
\hline $\mathbf{8} / \mathbf{1 6}$ & $63 / 60$ & 2 \\
\hline $\mathbf{1 7 / 1 8}$ & $48 / 56$ & 6 \\
\hline $\mathbf{1 9 / 2 0}$ & $56 / 59$ & 2 \\
\hline 6
\end{tabular}

Table 6 - Contaminant removal efficiency in the fixed bed tests.

Figure 1 shows the results of the Student t-test, in which the values to the right of the red line are statistically significant for a $95 \%$ confidence level. In view of this, we may state that parameter 1 (nitrogen content) was what most influenced the biodegradation process and that parameter $2(\mathrm{pH})$ in isolation was not significant for the process within the levels studied.

The negative values in the Pareto graph indicate that an increase in the factor in question has an unfavorable effect on the pollutant removal efficiency. It is further observed that the interactions between factor 1 and factors 2 and 3 are significant in this process, within the levels studied for each factor.

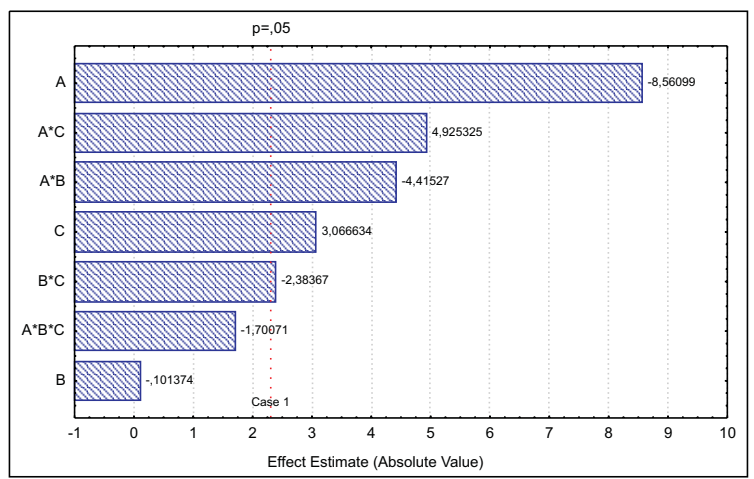

Fig. 1 - Pareto Chart for the Fixed Bed Tests (A - nitrogen content; $\mathrm{B}-\mathrm{pH}$; C - Aeration rate). 
Figure 2 shows the relationship between the $\mathrm{pH}$ and the nitrogen content in the soil, indicating that greater removal efficiency is achieved when the $\mathrm{pH}$ is adjusted to levels around neutrality and the nitrogen content is kept at the soil's natural level.

In Figure 3, the relationship between the nitrogen content and the aeration rate is shown, demonstrating that these are directly proportional parameters and that higher decontamination of the soil is obtained when no external nitrogen source is added and when a lower aeration rate $(3 \mathrm{~L} / \mathrm{h})$ is employed. An explanation for the higher biodegradation levels with a lower air flow could be that there was less drying of the soil, since moisture is an important parameter to be considered in bioremediation processes.

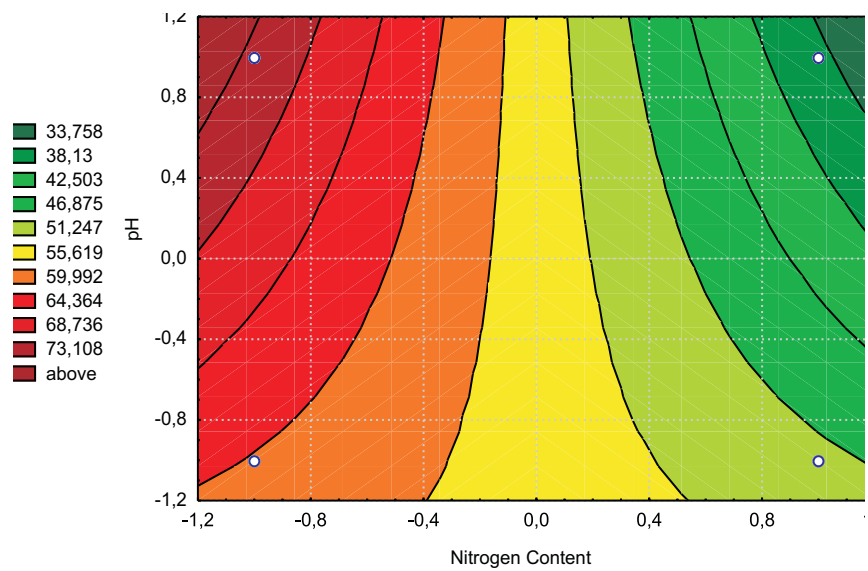

Fig. 2 - Fitted surface showing the interaction between the soil's nitrogen content and $\mathrm{pH}$.

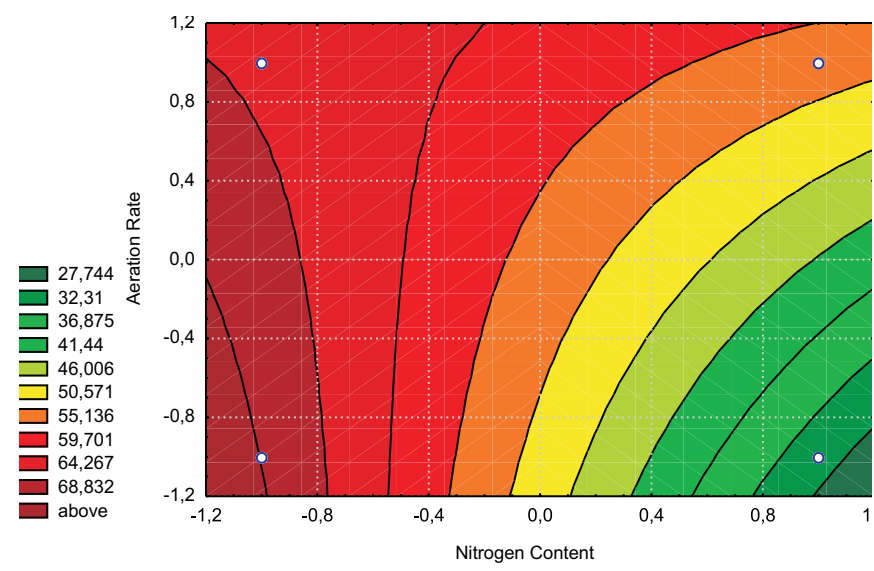

Fig. 3 - Fitted surface showing the interaction between the soil's nitrogen content and the reactor's aeration rate.

\section{CONCLUSIONS}

Given the results obtained, it may be stated that the soil used in this study can be treated using a bioremediation process. Efficiency of up to $45 \%$ in removing the contaminants was achieved in the tests conducted in slurry-phase reactors for 13 days, while $80 \%$ efficiency was reached in the tests in a fixed bed reactor, which lasted 30 days.

It is further noted that the variables assessed in the present study influenced greatly the biodegradation of the oil contained in the soil under study. What is more, the addition of an inoculum did not have the expected effect, showing that the naturally occurring microbial flora, which is best adapted to the soil conditions, operates effectively in decontaminating this medium.

\section{ACKNOWLEDGEMENTS}

FAPERJ, CAPES, CTPetro/FINEP, CENPES/Petrobras

\section{REFERENCES}

1. Wong,, J.H.C.; Lim, C.H.; Nolen, G.L., Design of Remediation Systems; Lewis Publishers Ed.; United States of America, 1997.

2. Stout, S.A. \& Lundegard, P.D., Intrinsic Biodegradation of Diesel Fuel in an Interval of Separate Phase; Applied Geochemistry, 1998, 13,851 .

3. Li, G.; Huang, W.; Lerner, D.N; Zhang X., Enrichment of Degrading Microbes and Bioremediation of Petrochemical Contaminants in Poluuted Soil, Wat. Res., 2000, 34, 3845.

4. Semple, K.T; Reid, B.J.; Fermor, T.R.; Impact of Composting Strategies on the Treatment of Soils Contaminated with Organic Pollutants, Environmental Pollution, 2001, 112, 269.

5. Jorgensen, K.S.; Puustinen, J.; Suortti, A.-M., Bioremediation of Petroleum Hydrocarbon-Contaminated Soil by Composting in Biopiles, Environmental Pollution, 2000, 107, 245.
6. Bardi, L.; Mattei, A.; Steffan, S., Marzona, M., Hydrocarbon Degradation by a Soil Microbial Population with b-Cyclodeztrin as Surfactant to Enhance Bioavailability, Enzime and Microbial Technology, 2000, 27, 709.

7. Apha, A., Standard Methods for the Examination of Water and Wastewater, WPCF Ed., New York, 1992.

8. Jaramillo, I.R., Fundamentos Teóricos-prácticos de Temas Selectos de la Ciencia del Suelo, Universidad Autónoma Metropolitana, México, 1996.

9. EMBRAPA,Manual de Métodos de Análise de Solo, Rio de Janeiro, 1997.

10. Volpon, A.G.T.; Vital, R.L.; Casella, R.C., Método NMP em Microescala para Contagem de Microrganismos Consumidores de Hidrocarbonetos, Comunicação Técnica SEBIO N.06/98. 